\title{
The Vicious Cycle of Economic Inequality: The Role of Ideology in Shaping the Relationship between "What Is" and "What Ought to Be" in 41 Countries
}

Efraín García-Sánchez.

Department of Social Psychology, University of Granada, Granada, Spain.

Jojanneke Van der Toorn

Department of Social, Health and Organisational Psychology, Utrecht University, The Netherlands

Department of Social and Organisational Psychology, Leiden University, The Netherlands

Rosa Rodríguez-Bailón

Department of Social Psychology, University of Granada, Granada, Spain.

Guillermo B. Willis.

Department of Social Psychology, University of Granada, Granada, Spain.

Corresponding author: Efraín García-Sánchez, Department of Social Psychology at the Mind, Brain, and Behaviour Research Center, University of Granada, Campus de Cartuja S/N P.C. 18011, Granada, Spain (email: egarcias@ correo.ugr.es).

\section{Author notes:}

The author(s) declared no potential conflicts of interest with respect to the research, authorship, and/or publication of this article.

Acknowledgments: This project was funded thanks to the doctoral scholarship given to the first author COLCIENCIAS-679 (Colombia), and the PSI2016-78839-P MINECO (Spain) grant given to third and fourth authors. We also want to thank Tom Wilderjans and Ruthie Pliskin for insightful comments in earlier versions of this manuscript. 


\begin{abstract}
People's desired levels of inequality are informed by the levels of inequality they perceive to exist. Perceived economic inequality is used as a reference point in determining people's ideal level of inequality. However, recent research has suggested that the strength of this relationship depends on people's endorsement of system justifying beliefs. The current paper extends this body of research by replicating these findings across 41 countries ( $\mathrm{N}=42078)$, showing the impact of system justifying beliefs at both the individual and the societal level. We conducted a multilevel analysis and found that the higher the endorsement of equality of opportunity beliefs - both at the individual and the societal level—, and meritocratic beliefs—at the individual level—, the stronger the relationship between perceived and ideal economic inequality. These findings are in support of a motivated account of the perceived legitimacy of economic inequality.
\end{abstract}

Key words: Economic inequality, perceptions of inequality, system justifying beliefs, societal beliefs, legitimacy 


\section{The Vicious Cycle of Economic Inequality: The Role of Ideology in Shaping the Relationship between "What Is" and "What Ought to Be" in 41 Countries}

Despite evidence of the pervasive and pernicious effects of economic inequality on health, wellbeing, happiness, trust, social cohesion, and mortality (Buttrick \& Oishi, 2017; Wilkinson \& Pickett, 2017), inequality tends to be widely accepted, and justified (Costa-Lopes, Dovidio, Pereira, \& Jost, 2013; Walker, 2014). In determining acceptable levels of economic inequality, people make use of existential standards - the current levels of national wealth and inequality that are perceived to exist. Thus, information about how economic resources are distributed (i.e., perceived inequality) is used in people's assessment of how they should be distributed (i.e., ideal inequality; Castillo, 2011; Hadler, 2005; Shamon \& Dülmer, 2014; Shepelak \& Alwin, 1986). However, little research has examined why this is the case.

In line with Willis, Rodríguez-Bailón, López-Rodríguez, and García-Sánchez (2015), we argue that the relationship between the perceived and ideal level of inequality is explained partially by a motivation to rationalize the status quo (i.e., system justification). Hence, ideologies - measured as individual differences in the endorsement of system justifying beliefs - moderate the effects of existential standards_-perceived inequality—on judgements of the ideal income distribution.

In this research, we aim to extend these findings in at least two ways: First, by replicating this interaction effect in bigger and more diverse samples from 41 countries; second, by demonstrating that the interaction also occurs at the societal level, such that the relationship between perceived and ideal inequality is stronger in those countries that are characterized by higher aggregated system justifying beliefs scores.

\section{Existential Standards and Ideal Estimates of Inequality}


The concept of existential standards and its relationship with the ideal estimations was coined by Shepelak and Alwin (1986) who proposed that what ought to be is defined "strictly in terms of established practices" (p. 31). Indeed, perceptions of the current state of affairs significantly shape ideal levels of inequality (Cimpian \& Salomon, 2014; Kay et al., 2009; Willis et al., 2015). When it comes to economic inequality, people who perceive greater income gaps in society have been found to also be the ones willing to accept greater income gaps (Castillo, 2012a; Trump, 2017; Willis et al., 2015). Similarly, in countries with greater objective economic inequality, people perceived greater inequality (Castillo, 2012b) and reported higher levels of tolerance for inequality (Schröder, 2017). Thus, economic inequality provides a reference point for the formation of the existential standards used to evaluate the status quo.

The relationship between perceived and desired inequality may be due to heuristic processes, so that people anchor their responses on the current information available in their more immediate context (Tversky \& Kahneman, 1974). For instance, people that were provided information about actual income inequality used it as an anchor to estimate the desired levels of inequality (Pedersen \& Mutz, 2018). However, there is also evidence that supports a motivational component that leads people to justify their status quo (Jost \& Banaji, 1994; van der Toorn \& Jost, 2014). That is, people perceive inequality as an acceptable state of affairs (Kay et al., 2009), and justify it by endorsing ideologies that rationalize inequality (Jost \& Hunyady, 2005).

\section{System Justifying Ideologies and the Motivational Underpinnings of Perceived}

\section{Economic Inequality}

According to system justification theory, people are motivated to justify existing social, political and economic arrangements in order to fulfill psychological needs for meaning, order, and stability (Jost, Gaucher, \& Stern, 2015; van der Toorn \& Jost, 
2014). Certain ideologies contribute to meeting these needs by providing narratives through which people make sense of their-unequal—realities.

Meritocratic beliefs, which posit that rewards are based upon individual merits (i.e., hard work, ability or talent; Jost \& Hunyady, 2005), are central to the legitimation of economic inequality (see Kluegel \& Smith, 1986; Shepelak, 1989). These beliefs are particularly stable and widespread in Western societies, and are associated with judgments of how economic resources should be distributed (Kunovich \& Slomczynski, 2007) and help to maintain social cohesion in unequal societies (Duru-Bellat \& Tenret, 2012).

Alongside meritocratic beliefs, equality of opportunity beliefs also play a role in the legitimation of economic inequality (Kluegel \& Smith, 1986; Shepelak \& Alwin, 1986). This type of beliefs relies on the "level-the-playing-field" principle (Roemer, 1998), which posits that society should provide the resources people need to develop their potential (e.g., education) to compete for valued social positions.

Though related, meritocratic and equality of opportunity beliefs stress two different dimensions of how economic inequalities are justified: merit refers to the bases on which resources are distributed (e.g., competence, talent, effort), whereas equality of opportunity refers to the conditions that allow the development of such merits (Mijs, 2016). Both types of beliefs can be depicted as descriptive or prescriptive beliefs. The former refers to factual perceptions that meritocracy and equal opportunities do exist in society, whereas the latter refers to preferences for the merit and equal opportunities principles, that is, how resources should be allocated. Descriptive (but not prescriptive) meritocratic beliefs have been shown to play a hierarchy-legitimizing function (Son Hing et al., 2011). 
Beliefs are also held at the societal level. These societal beliefs are "enduring beliefs shared by society members, with contents that are perceived by society members as characterizing their society" (p. 39, Bar-Tal, 2000); they are shared cognitions that mirror a common perceived reality, and go beyond the beliefs of individuals. Societal beliefs help to structure social life (e.g., setting behavioral norms and institutions; BarTal, Sharvit, Halperin, \& Zafran, 2012); and are entrenched in socio-historical narratives, collective memory, public debates, media products, and institutional communication (Bar-Tal, 2000). Hence, societal beliefs become a "meaning template" to interpret and navigate reality, which contribute to legitimize the status quo, even before rampant levels of violence, unfairness and inequality (Bar-Tal, 2007; Bar-Tal, Raviv, Raviv, \& Dgani-Hirsh, 2009; Sharvit, 2014).

In addition, societal beliefs serve as social cues that may influence individuals' judgments of their reality. From a social judgment perspective, aggregated judgmentssocietal beliefs - create "consensus" about what is normative and desirable in a given context, which accordingly enhances individual judgments about what is legitimate (Bitektine, 2011; Bitektine \& Haack, 2015).

Situational factors can also trigger individuals' motivation to justify the system. For instance, under system threat, people strongly endorsed meritocratic beliefs and worked harder on behavioral tasks in defense of the meritocratic system (Ledgerwood, Mandisodza, Jost, \& Pohl, 2011). Similarly, meritocracy reminders via priming have been shown to lead disadvantaged groups to justify inequality by self-stereotyping (McCoy \& Major, 2007), or by denying racial discrimination (Knowles, \& Lowery, 2012). Thus, ideologies — both at the individual and at the societal level — are part of a multilevel process that reinforces the legitimacy of the current state of affairs. Individual beliefs help people to justify the status quo by judging it as proper and fair; 
and societal beliefs provide a sense of validation that reinforces individual judgments (Bitektine \& Haack, 2015). Indeed, people's endorsement of narratives of modernity, both at the individual and the country level are related to more acceptance of income inequality (Larsen, 2016). Thus, the acceptance of economic inequality is the result of an active interplay between socioeconomic and dominant ideologies within and between countries (Hadler, 2005).

\section{The Current Research}

The first aim of this study was to replicate previous research examining the moderating role of system justifying beliefs on the relationship between the economic inequality individuals perceive and the inequality they consider ideal. Although Willis and colleagues (2015) have already shown that this relationship was stronger when system justification motivation was enhanced, they collected data from convenience samples in the Spanish context and used a measure of social dominance orientation to operationalize system justification. The current study tests the robustness of these previous findings by using a large cross-national sample and by including other system justifying beliefs in the model (i.e., meritocratic and equality of opportunity beliefs). Moreover, we also explore the influence of the societies' ideological climate by testing the role of system justifying beliefs at the societal level on individual estimations of economic inequality.

Our first hypothesis was that system justifying beliefs - meritocratic and equality of opportunity beliefs - moderate the positive relationship between perceived and ideal economic inequality within countries, such that the relationship would be stronger among respondents who highly endorse these two system justifying ideologies $\left(\mathrm{H}_{1}\right)$. Our second hypothesis is that these relationships also hold at the country-level: the higher endorsement of system justifying beliefs at the societal level, the stronger the 
positive relationship between respondents' perceived and desired level of economic inequality $\left(\mathrm{H}_{2}\right)$. This will allow us to test the intriguing possibility that above and beyond people's own endorsement of system justifying beliefs, the ideological climate that surrounds them influences their desired level of inequality.

\section{Method}

\section{Data and Respondents}

We used data from the Social Inequality Module carried out by the International Social Survey Programme (ISSP) in 2009 (ISSP Research Group, 2012). This module included surveys of 41 countries around the world ( $N=56021$ respondents). We used all data available to estimate each model, and applied a listwise deletion method when there were missing data in the variables of interest. Final analyses were conducted with $N=42078$ cases $\left(M_{\text {age }}=46.75, S D=17.20 ; 55.01 \%\right.$ female $)$.

\section{Outcome Variable}

Ideal economic inequality. This variable corresponds to the estimations of how income is ideally distributed among high vs. low status occupations. It was calculated by computing the ratio between the earnings considered as fair for a chairman of a large national company, and an unskilled worker in a factory. Considering that the logarithmic function helps this measure meet important assumptions regarding perceptions of economic differences (i.e., loss aversion, scale invariance, and symmetry), we log-transformed the ratio as suggested by the literature ${ }^{1}$ (Jasso, 1978; Jasso, Törnblom, \& Sabbagh, 2016).

\section{Predictor Variables}

\footnotetext{
${ }^{1}$ The logarithm of the ratio is used in accordance with the literature, given that the log transformation attenuates the differences made at the top and at the bottom of the scores (e.g., a difference of 10 between 990 and 1000 does not have the same meaning as a difference of 10 between 90 and 100; for a more extensive explanation, see Jasso, 2015; Jasso, Törnblom, \& Sabbagh, 2016).
} 
Perceived economic inequality. This variable was operationalized as respondents' individual estimations of the ratio between current earnings of a chairman of a large national company and an unskilled worker in a factory. This variable was calculated using the same procedure used to calculate ideal economic inequality, but using respondents' estimates of the salary that those workers actually earn.

Meritocratic beliefs. These beliefs represent the idea that getting ahead in life is due to individual effort and ambition. They were operationalized as the average score of two items, where respondents were asked to indicate on a scale from 1 (essential) to 5 (not important at all), "How important is hard work?" and "How important is having ambition?" for getting ahead in life $\left(r_{(54607)}=.426, p<.001\right){ }^{2}$ The items were reversescored such that higher values indicate higher levels of endorsement of meritocratic beliefs.

Equality of opportunity beliefs. These beliefs refer to the credence that people have equal access to opportunities to get ahead in life, regardless of systematic groupbased bias in education. We operationalized equality of opportunity beliefs as the average score of the following three items, with response scales ranging from 1 (strongly agree) to 5 (strongly disagree): "In <country>, only students from the best secondary schools have a good chance to obtain a university degree"; "In <country>, only the rich can afford the costs of attending university"; and "In <country>, people have the same chances to enter university, regardless of their gender, ethnicity or social background" (reverse-scored) $\left(\alpha=.584^{3}, N=54083\right)$. Higher values indicate stronger endorsement of the belief that people have equal access to opportunities.

\section{Individual Socio-Demographic Variables}

\footnotetext{
${ }^{2}$ Zero-order correlations for each country are provided in the supplementary materials Table S1.

${ }^{3}$ This overall alpha level is relatively low, which is not surprising as survey items reliabilities are "generally mediocre at best" (Feldman, 1999). Despite this, we decided to use this measure because it has been successfully used in other international surveys, allowing comparison with similar research in the field. See Table S2 in the supplementary materials for Cronbach's alpha per country.
} 
We additionally included two status indicators in the analysis to control for their possible effects: respondents' subjective socioeconomic status and their educational level. The first was measured using the MacArthur Scale of subjective SES (Adler, Epel, Castellazzo, \& Ickovics, 2000). On an image of a ladder with ten rungs, numbered from 1 (the lowest position) to 10 (the highest position), respondents indicated where they would place themselves on such a scale. The second status indicator was educational level, which was scored from 0 (no formal degree) to 5 (university degree). Respondent sex $($ Male $=0$, Female $=1)$ and age were included as control variables.

\section{Societal Level Variables}

As objective economic inequality indicators at the societal level we included the Gini index to account for economic inequality, and the Gross Domestic Product per capita (GDP) based on purchasing power parity — an overall wealth indicator that converts the values of goods and services from different countries into the values of a country of reference, so comparisons between countries can be made - . Both the Gini index and the GDP were retrieved from the World Development Indicators (World Bank, 2018) for the year in which the ISSP data were collected. When data were not available in this dataset, we retrieved information from The World Factbook published by the Central Intelligence Agency (Central Intelligence Agency, 2018).

We aggregated the individual scores for perceived inequality and system justifying beliefs within each country to be able to also examine the variance of those variables at the societal level and test their influence on respondents' estimations of ideal inequality. Aggregating variables from lower levels into grouping variables at higher levels (e.g., groups, communities, countries, etc.) is a common practice in multilevel modelling to take care of the ecological fallacy when testing micro- and macro-level relationships (Heck \& Thomas, 2015; Hox, 2010). Analyses were 
conducted using the lme4 package implemented for R Software (Bates, Mächler, Bolker, \& Walker, 2015).

\section{Results}

Due to the nested nature of the data, with individuals (Level-1) clustered in countries (Level-2), we estimated a series of Multilevel Models (MLM) to test our hypotheses. MLM takes into account that respondents within countries may be more strongly correlated with each other, and provides better estimations than regular OLS regression. We estimated a random slope-intercept model, to account for the variability of the outcome intercept and predictors aside from the sociodemographic variables across countries. Individual-level variables were group-mean centered, and societallevel variables were grand-mean centered to conduct the within- and cross-level interactions (Preacher, Zhang, \& Zyphur, 2016). Descriptive statistics are shown in Table 1 and full information for each model is presented in Table 2.

Table 1.

Descriptive statistics for variables included in the model at the individual and societal level

\begin{tabular}{lccccc}
\hline \multicolumn{1}{c}{ Individual level } & $N$ & Mean & SD & Min & Max \\
\hline Ideal income gap & & & & & \\
Perceived income gap & 42078 & 1.71 & 1.16 & -10.60 & 13.59 \\
Meritocratic beliefs & 42078 & 2.59 & 1.37 & -10.40 & 13.82 \\
Equality of opportunity beliefs & 42078 & 3.98 & 0.75 & 1.00 & 5.00 \\
Status (educational level) & 42078 & 3.28 & 0.88 & 1.00 & 5.00 \\
Subjective SES & 42078 & 2.95 & 1.43 & 0.00 & 5.00 \\
$\quad$ Societal level & 42078 & 5.12 & 1.77 & 1.00 & 10.00 \\
Ideal income gap & & & & & \\
Perceived income gap & 41 & 1.58 & 0.51 & 0.78 & 3.34 \\
Meritocratic beliefs & 41 & 2.47 & 0.67 & 1.41 & 3.99 \\
Equality of opportunity beliefs & 41 & 3.94 & 0.26 & 3.47 & 4.39 \\
Status (educational level) & 41 & 3.32 & 0.35 & 2.52 & 4.19 \\
Subjective SES & 41 & 2.86 & 0.46 & 1.77 & 3.65 \\
Gini index & 41 & 5.05 & 0.65 & 3.74 & 6.12 \\
Gross Domestic Product (purchase & 41 & 34.57 & 7.77 & 24.8 & 63 \\
power parity) & 41 & 27901.73 & 12176.03 & 5115.48 & 50344.51 \\
\hline
\end{tabular}


Running head: SYSTEM JUSTIFYING BELIEFS AND PERCEIVED ECONOMIC INEQUALITY

Note: See supplementary material for descriptive statistics per country Table S2. 


\section{Table 2.}

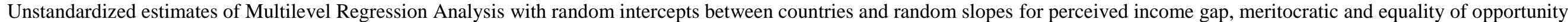
beliefs, estimated with Full Maximum Likelihood Estimator.

\begin{tabular}{|c|c|c|c|c|c|c|c|c|c|c|c|c|c|c|c|}
\hline & \multicolumn{3}{|c|}{ Model 0. Intercept only } & \multicolumn{3}{|c|}{ Model 1. Control variables } & \multicolumn{3}{|c|}{$\begin{array}{c}\text { Model 2. Perceptions }+ \\
\text { Individual beliefs (fixed } \\
\text { slopes) }\end{array}$} & \multicolumn{3}{|c|}{$\begin{array}{c}\text { Model 3. Perceptions }+ \\
\text { Individuals beliefs (random } \\
\text { slopes) }\end{array}$} & \multicolumn{3}{|c|}{$\begin{array}{l}\text { Model 4. Perception + } \\
\text { Individual and societal } \\
\text { Beliefs (random slopes) } \\
\end{array}$} \\
\hline & $B(S E)$ & $95 \% C I$ & $p$ & $B(S E)$ & $95 \% C I$ & $p$ & $B(S E)$ & $95 \% C I$ & $p$ & $B(S E)$ & $95 \% C I$ & $p$ & $B(S E)$ & $95 \% C I$ & $p$ \\
\hline \multicolumn{16}{|l|}{ Fixed Parts } \\
\hline (Intercept) & $\begin{array}{l}1.592 \\
(.078)\end{array}$ & $\begin{array}{c}1.440- \\
1.745\end{array}$ & $<.001$ & $\begin{array}{l}1.432 \\
(.079)\end{array}$ & $\begin{array}{c}1.277- \\
1.587\end{array}$ & $<.001$ & $\begin{array}{l}1.593 \\
(.078)\end{array}$ & $\begin{array}{l}1.439- \\
1.746\end{array}$ & $<.001$ & $\begin{array}{l}1.572 \\
(.079)\end{array}$ & $\begin{array}{l}1.418- \\
1.726\end{array}$ & $<.001$ & $\begin{array}{l}1.563 \\
(.034)\end{array}$ & $\begin{array}{c}1.498- \\
1.629\end{array}$ & $<.001$ \\
\hline Status (educational level) & & & & $\begin{array}{l}.076 \\
(.004)\end{array}$ & $\begin{array}{l}.068- \\
.083\end{array}$ & $<.001$ & $\begin{array}{l}.023 \\
(.003)\end{array}$ & $\begin{array}{l}.017- \\
.029\end{array}$ & $<.001$ & $\begin{array}{l}.028 \\
(.003)\end{array}$ & $\begin{array}{l}.022- \\
.034\end{array}$ & $<.001$ & $\begin{array}{l}.028 \\
(.003)\end{array}$ & $\begin{array}{l}.022- \\
.034\end{array}$ & $<.001$ \\
\hline Subjective SES & & & & $\begin{array}{l}.024 \\
(.003)\end{array}$ & $\begin{array}{l}.018- \\
.029\end{array}$ & $<.001$ & $\begin{array}{l}.030 \\
(.002)\end{array}$ & $\begin{array}{l}.025- \\
.034\end{array}$ & $<.001$ & $\begin{array}{l}.029 \\
(.002)\end{array}$ & $\begin{array}{l}.024- \\
.033\end{array}$ & $<.001$ & $\begin{array}{l}.029 \\
(.002)\end{array}$ & $\begin{array}{l}.024- \\
.034\end{array}$ & $<.001$ \\
\hline Sex (female) & & & & $\begin{array}{l}-.159 \\
(.009)\end{array}$ & $\begin{array}{l}-.177- \\
-.141\end{array}$ & $<.001$ & $\begin{array}{l}-.081 \\
(.008)\end{array}$ & $\begin{array}{l}-.096- \\
-.065\end{array}$ & $<.001$ & $\begin{array}{l}-.087 \\
(.008)\end{array}$ & $\begin{array}{l}-.102- \\
-.072\end{array}$ & $<.001$ & $\begin{array}{l}-.087 \\
(.008)\end{array}$ & $\begin{array}{l}-.102- \\
-.072\end{array}$ & $<.001$ \\
\hline Age & & & & $\begin{array}{l}.005 \\
(.000)\end{array}$ & $\begin{array}{l}.005- \\
.006\end{array}$ & $<.001$ & $\begin{array}{l}.001 \\
(.000)\end{array}$ & $\begin{array}{l}.001- \\
.002\end{array}$ & $<.001$ & $\begin{array}{l}.002 \\
(.000)\end{array}$ & $\begin{array}{l}.001- \\
.002\end{array}$ & $<.001$ & $\begin{array}{l}.002 \\
(.000)\end{array}$ & $\begin{array}{l}.001- \\
.002\end{array}$ & $<.001$ \\
\hline Perceived income gap (PIG) & & & & & & & $\begin{array}{l}.529 \\
(.003)\end{array}$ & $\begin{array}{l}.522- \\
.535\end{array}$ & $<.001$ & $\begin{array}{l}.496 \\
(.017)\end{array}$ & $\begin{array}{l}.463- \\
.528\end{array}$ & $<.001$ & $\begin{array}{l}.499 \\
(.016)\end{array}$ & $\begin{array}{l}.468- \\
.529\end{array}$ & $<.001$ \\
\hline Meritocratic beliefs (MB) & & & & & & & $\begin{array}{l}.021 \\
(.005)\end{array}$ & $\begin{array}{l}.011- \\
.032\end{array}$ & $<.001$ & $\begin{array}{l}.021 \\
(.008)\end{array}$ & $\begin{array}{l}.004- \\
.037\end{array}$ & .015 & $\begin{array}{l}.021 \\
(.008)\end{array}$ & $\begin{array}{l}.004- \\
.037\end{array}$ & .014 \\
\hline $\begin{array}{l}\text { Equality of opportunity beliefs } \\
\text { (EQB) }\end{array}$ & & & & & & & $\begin{array}{l}.059 \\
(.005)\end{array}$ & $\begin{array}{l}.050- \\
.069\end{array}$ & $<.001$ & $\begin{array}{l}.059 \\
(.008)\end{array}$ & $\begin{array}{l}.043- \\
.075\end{array}$ & $<.001$ & $\begin{array}{l}.059 \\
(.008)\end{array}$ & $\begin{array}{l}.043- \\
.074\end{array}$ & $<.001$ \\
\hline PIG x MB & & & & & & & $\begin{array}{l}.013 \\
(.005)\end{array}$ & $\begin{array}{l}.003- \\
.022\end{array}$ & .008 & $\begin{array}{l}.010 \\
(.005)\end{array}$ & $\begin{array}{l}.001- \\
.019\end{array}$ & .033 & $\begin{array}{l}.010 \\
(.005)\end{array}$ & $\begin{array}{l}.001- \\
.019\end{array}$ & .033 \\
\hline PIG x EQB & & & & & & & $\begin{array}{l}.031 \\
(.004)\end{array}$ & $\begin{array}{l}.023- \\
.039\end{array}$ & $<.001$ & $\begin{array}{l}.028 \\
(.004)\end{array}$ & $\begin{array}{l}.021- \\
.036\end{array}$ & $<.001$ & $\begin{array}{l}.029 \\
(.004)\end{array}$ & $\begin{array}{l}.021- \\
.036\end{array}$ & $<.001$ \\
\hline $\begin{array}{l}\text { Perceived income gap (PIG-E) } \\
\text { (L-2) }\end{array}$ & & & & & & & & & & & & & $\begin{array}{l}.679 \\
(.050)\end{array}$ & $\begin{array}{l}.581- \\
.777\end{array}$ & $<.001$ \\
\hline Meritocratic beliefs (L-2) & & & & & & & & & & & & & $\begin{array}{l}.146 \\
(.127)\end{array}$ & $\begin{array}{l}-.103- \\
.394\end{array}$ & .251 \\
\hline $\begin{array}{l}\text { Equality of opportunity beliefs } \\
\text { (L-2) }\end{array}$ & & & & & & & & & & & & & $\begin{array}{l}.206 \\
(.132)\end{array}$ & $\begin{array}{l}-.054- \\
.465\end{array}$ & .120 \\
\hline
\end{tabular}


Table 2. (Continued)

Model 0.

Gini index (2009)

GDP per capita by PPP (2009)

PIG x MB (L-2)

PIG x EQB (L-2)

\section{Random Parts}

Individual variance

Intercept variance

1.019

.253

.995

.251

Perceived income gap

Meritocratic beliefs

Equality of Opportunity beliefs

Covariance PIG x Intercept

\begin{tabular}{lr}
$\mathrm{ICC}$ & .199 \\
\hline $\mathrm{N}(\mathrm{L}-1)$ & 47005 \\
$\mathrm{~N}(\mathrm{~L}-2)^{+}$ & 42 \\
$\mathrm{R}^{2}$ & .234
\end{tabular}

AIC

134511.93

BIC

134538.21

134505.93

46168

131018.51

13110.51
Model 2.

Model 3.

Model 4.

$B(S E) \quad 95 \% C I \quad p$

$\begin{array}{lll}.004 & -.003-\quad .237\end{array}$

(.004) $\quad .012$

$-.043-.124$

(.041) $\quad .037$

$.046 \quad-.077-$

(.063) $\quad .169$

$.093 \quad .005-$

(.045) $\quad .181$

.291

462

.039

$.631 \quad .612$

$.252 \quad .252$

.612

.040

.009

.002

.002

.680

.062

42078

42078

42

.533

100335.19

100438.96

131004.51

\section{2}

.548

99169.25

99368.14

99123.25

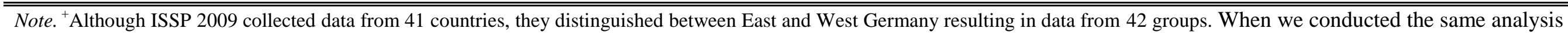
excluding outliers - respondents with scores above and below 4 SD_results were nearly identical. 
Model 0 is the intercept-only model, which provided fairly good evidence of substantial intraclass correlation (ICC=.199) and between-level variance in the outcome variable to warrant multilevel modeling. Model 1 includes the status indicators and the sociodemographic variables in order to control for them in further models. Model 2 includes perceptual and ideological variables at the individual level, as well as their interaction term. Given that multilevel models that maximize the random effects variance perform more sensitive tests (Barr, Levy, Scheepers, \& Tily, 2013), in Model 3 we added random effects for perceived income gap, and for meritocratic and equality of opportunity beliefs. Model 4 is the final model, where we additionally tested the effect of societal variables.

Across all models, SES was found to positively predict ideal income inequality. For each unit increase in educational level, respondents' estimation of the ideal economic inequality increased by $2.84 \%{ }^{4}$. The same was found for subjective SES, such that each unit increase on this scale translated into a $2.94 \%$ increase in respondents' estimation of the ideal economic inequality. This is consistent with previous research on the influence of status (Castillo, 2012a; Kelley \& Evans, 1993) and self-interest motivations (Brown-Iannuzzi, Lundberg, \& McKee, 2017; Sznycer et al., 2017), suggesting that high SES respondents accept higher levels of economic inequality as a way to justify their privileged position.

\section{Perceived Inequality and Individual System Justifying Beliefs Influence}

\section{Estimations of Ideal Inequality}

According to our hypotheses, desired levels of economic inequality are influenced by perceptions of existing inequality and system justifying beliefs. Model 4 shows that the perceived level of economic inequality predicted the ideal level of

\footnotetext{
${ }^{4}$ The formula to transform Log-Log and Liner-Log indices is reported in the Supplementary material Appendix 1.
} 
inequality: each $10 \%$ increase in perceived inequality was found to be associated with a $4.86 \%$ increase in ideal inequality. Meritocratic beliefs and perceived equal access to opportunities both also positively predicted the ideal economic inequality; and this association was stronger for equality of opportunity beliefs than for meritocratic beliefs $(z=3.358, p<.001)^{5}$. For meritocratic beliefs, each unit increase was associated with a $2.12 \%$ increase in judgments of ideal inequality, and for the equality of opportunity beliefs there was a $5.97 \%$ increase.

Regarding our first hypothesis, both two-way interaction terms between perceived inequality and system justifying beliefs - meritocratic and equality of opportunity beliefs, respectively—were found to be associated with ideal levels of inequality (see Table 2). Thus, the relationship between perceived and ideal inequality was stronger for respondents endorsing higher levels of meritocratic beliefs (i.e., $+1 S D$; $b=.506, t=31.52, p<.001)$, than for those endorsing lower levels (i.e., $-1 S D)(b=.491$, $t=30.58, p<.001$ ) (Figure 1, panel A). Equality of opportunity beliefs also positively affected the relationship between perceived and ideal economic inequality, such that the more strongly respondents endorsed these beliefs, the stronger was the relationship between perceived and ideal economic inequality. We found that this association was stronger at higher levels of equality of opportunity beliefs $(b=.522, t=32.46, p<.001)$ than at lower levels $(b=.475, t=29.72, p<.001)$ (Figure 1, panel B).

\footnotetext{
${ }^{5}$ The difference between two regression coefficients was estimated using the formula $Z=\frac{b 1-b 2}{\sqrt[2]{S E b 1^{2}+S E b 2^{2}}}$, as proposed by Paternoster, Brame, Mazerolle, \& Piqueiro (1998).
} 

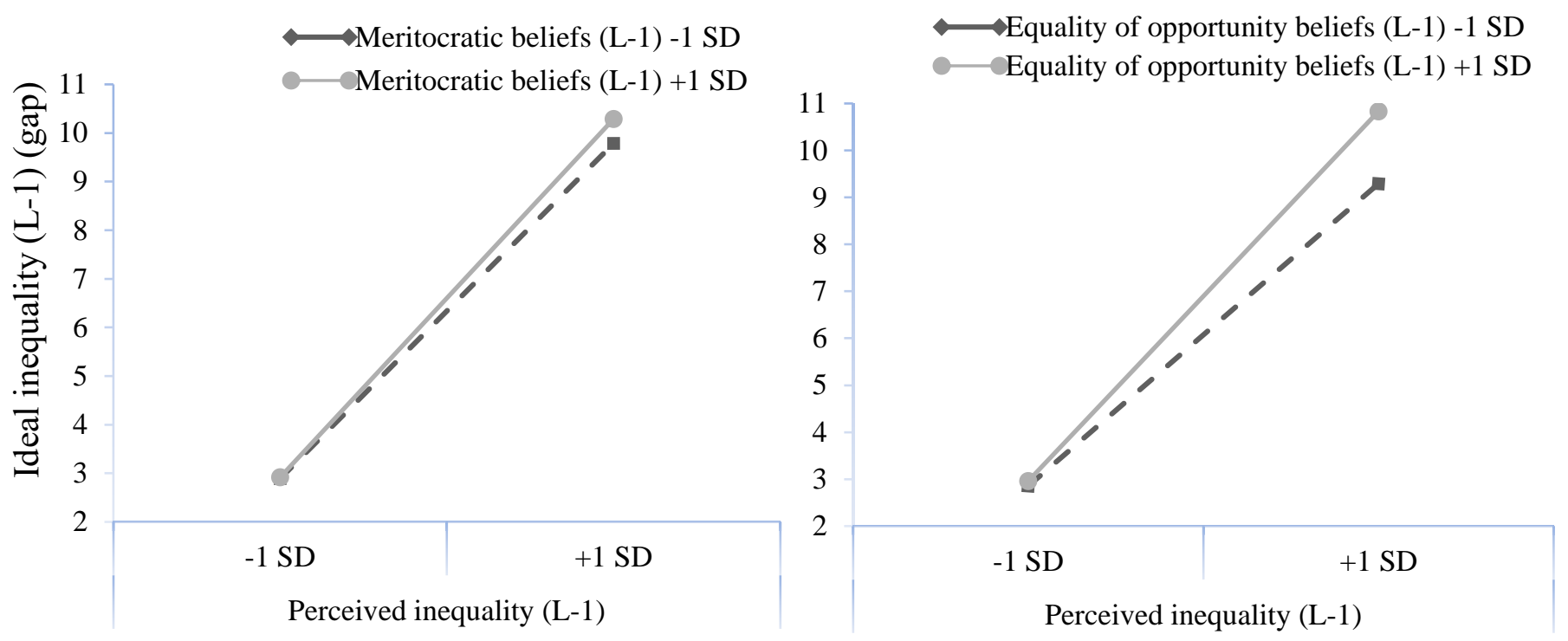

Figure 1. Within-level interaction between perceived inequality and meritocratic beliefs (Panel A), and equality of opportunity beliefs (Panel B), on ideal inequality.

\section{The Influence of Societal Variables on Estimations of Ideal Economic Inequality}

As for the role of societal variables, after controlling for individual variability between and within countries, we found that objective indices of inequality and wealth were not associated with the ideal levels of inequality that respondents desired.

However, as hypothesized, perceived economic inequality at the societal level was found to predict individual levels of desired economic inequality $(b=.679, p<.001)$. For each $10 \%$ increase in perceived inequality at the societal level, there was a $6.68 \%$ increase in ideal inequality at the individual level. Meritocratic and equality of opportunity beliefs at the country level were not associated with the desired levels of economic inequality.

We also confirmed our second hypothesis that societal beliefs would moderate the relationship between perceived and ideal inequality at the individual level, adjusting for individual beliefs. We found a cross-level interaction between equality of opportunity beliefs at the societal level and the perceived inequality at the individual 
level, indicating that the relationship between perceived and ideal economic inequality was stronger for residents of countries with higher aggregated levels of equality of opportunity beliefs $(b=.527, t=24.77, p<.001)$ compared to countries that endorse lower levels $(b=.461, t=19.60, p<.001)$ (Figure 2$)$. After specifying a random slope-intercept model (model 4), we did not find a cross-level interaction between meritocratic beliefs at the societal level and perceived inequality on ideal economic inequality.

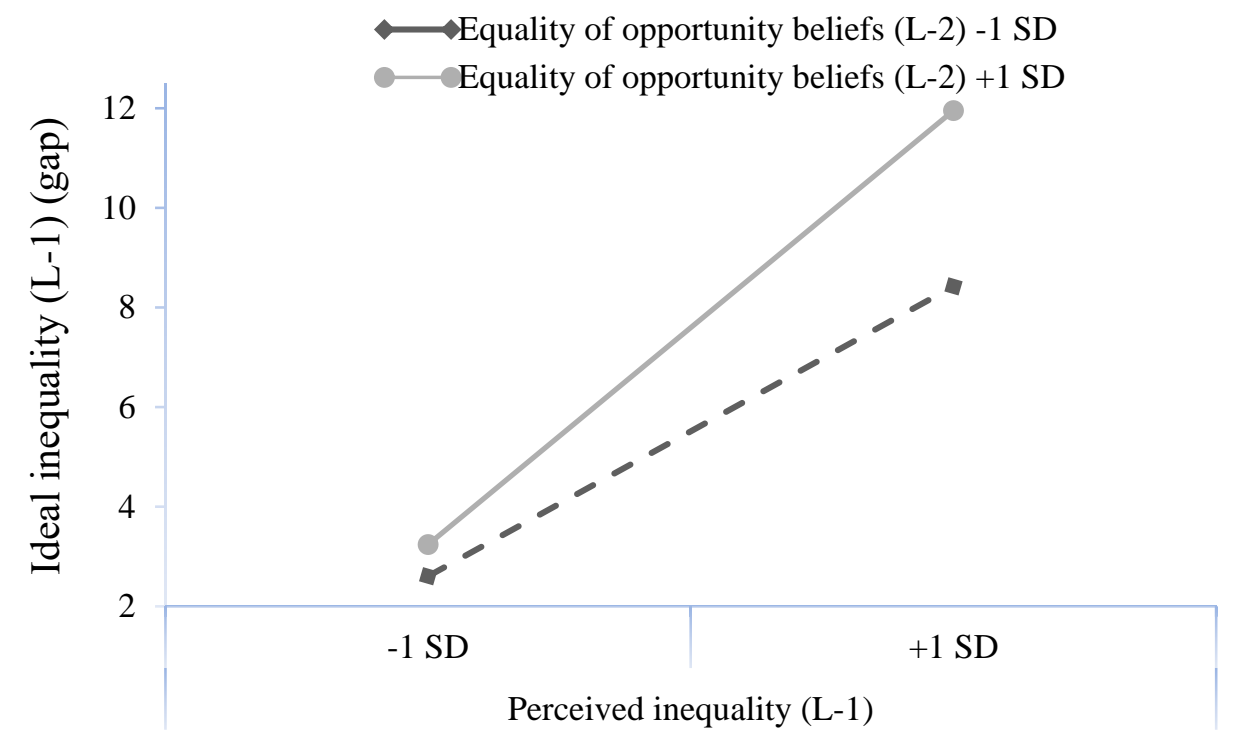

Figure 2. Cross-level interaction between perceived inequality at the individual level and equality of opportunity beliefs at the country level, on ideal inequality.

\section{Discussion}

The aim of this paper was to investigate the moderating role of system justifying beliefs on the relationship between perceived and ideal economic inequality. Although previous research has shown a consistent association between the perception of the current level of inequality and its ideal level (Castillo, 2012a; Kay et al., 2009; Trump, 2017), our findings provide further support for the moderation of this relationship by system justifying beliefs. In fact, we demonstrate that the relationship between perceived and ideal economic inequality is stronger among individuals who endorse 
meritocratic and equality of opportunity beliefs. This moderating role of ideologies was obtained at both the individual and the societal level.

Our findings replicate previous work demonstrating that adherence to ideologies that legitimate the status quo boosts the perceived-ideal economic inequality relationship (Willis et al., 2015). Considering that previous findings were obtained using smaller samples from a specific European country (i.e., Spain), the current research takes this work a step further by providing evidence of the robustness of the effect across national contexts.

Other work has also examined ideologies that justify economic inequality at the macro level. Larsen (2016), for instance, identified that narratives related to expectancies of upward social mobility, procedural justice, and belief of living in a middle-class society, are ways to accept more inequality. Our research findings are consistent with this previous work because they suggest a role for system justifying narratives in making sense of inequality, but contribute new insights too. First, our outcome variable relies on the distribution of income that people judge as ideal, which is different from the general judgment that income inequality in a given country is too large. This constitutes a different and more accurate operationalization of the ideal economic inequality that people would be willing to accept, than the indicator that "inequality is too large", which has been interpreted in diverse ways (e.g., tolerance of inequality, attitudes toward inequality, general perception, acceptance, concerns). Therefore, we argue that the estimation of income gaps is a useful alternative to measure perceptions and acceptance of economic inequality.

Second, we shed light on the social psychological underpinnings of the acceptance of inequality by demonstrating how system justifying ideologies shape the perceived-ideal inequality relationship. People are not simply anchoring on what they 
perceive to be the status quo, as their judgments of the ideal level of inequality are reinforced by their endorsement of system justifying beliefs. Although people's perceptions of the current level of inequality provide a reference point that anchor their judgments of what should be (Kay et al., 2009), we show that this anchoring is facilitated by people's ideological beliefs. We argue that the heuristic- and motivationbased approach do not compete in explaining why people legitimate economic inequality; rather, they depict two different and complementary mechanisms through which individuals contribute to the maintenance of the status quo. Although previous research has demonstrated the effect of the anchoring effect on judgments about economic inequality (Pedersen \& Mutz, 2018); we provide evidence that the process is also motivated, so that ideologies affect how perceptions of existing inequality affect the acceptance of inequality. In this line, more research should be conducted to test the interplay between the heuristic- and motivated-based approaches to the legitimation of inequality.

Third, we also found that the relationship between how much inequality people perceive and how much inequality they desire was stronger not just among individuals who endorse greater system justifying beliefs, but also for individuals living in countries that are characterized by beliefs that everyone has a chance to get ahead in life. Thus, even though individuals themselves may not necessarily endorse system justifying beliefs, the ideological context in which they live also plays a relevant role in their judgments of ideal economic inequality. This is a novel observation that extends the existing research on the justification of economic inequality in important ways. First, we showed that the higher the perceived inequality at the country level, the higher the ideal level of inequality at the individual level. Second, we showed that pervasive societal beliefs posing that everyone has a chance to get ahead, were associated with a 
stronger relationship between perceived and ideal inequality. These findings suggest that the cultural narratives that are shared and formed over time in a society have an important role in influencing individual perceptions, values, and positioning toward social phenomena.

These findings at the societal level might be explained from two different but complementary approaches. One of them comes from a social norms perspective, and argues that people use widespread beliefs to discern what to do or what to think. As such, social norms express social values (Sheriff, 1936) and prescribe attitudes and behaviors internalized by individuals (Rutland \& Cameron, 2016). Then, what is perceived in the social climate can give a sense of consensual validation that leads people to reaffirm such perceptions as prescriptive, and consequently, contributes to the justification and perpetuation of the status quo (Bitektine \& Haack, 2015). An alternative explanation is related to the motivation to justify the status quo (Jost, Gaucher, \& Stern, 2015). Previous research has shown that contextual stimuli that activate system justifying ideologies, can trigger people's motivations to justify the status quo (Ledgerwood et al., 2011; McCoy \& Major, 2007). In this perspective, the adherence to societal beliefs that justify inequality can fulfill epistemic and relational needs by providing a coherent and shared narrative that explains the world, which maximizes the relationship between what is and what ought to be (Jost, Sterling, \& Langer, 2015). Although both perspectives are plausible, we argue that societal beliefs are not just social norms that prescribe what should be, but could also trigger individual motivations to justify the current state of affairs. However, further research is needed to clarify how the ideological climate influences individual perceptions and judgments about inequality. 
The conditioning role of societal beliefs on perceived inequality should be interpreted with caution and still requires more robust testing in future research. Given the relatively small number of groups included in this research, and the difficulty of increasing the number of participating countries, future research might use other grouplevel clustering (e.g., organizations with different ideological climates) to increase the statistical power of the contextual level and get more robust estimates of these crosslevel effects. Likewise, to overcome potential limitations derived from the aggregation of individual-level indicators, ideological climate could also be captured through direct contextual indicators (e.g., organizational culture).

Additionally, we found that, at the individual level, meritocratic beliefs had a smaller effect on ideal inequality, than equality of opportunity beliefs; and, at the societal level, only equality of opportunity beliefs moderated the relationship between perceived and ideal inequality. Although we had expected to find a stronger influence of meritocratic beliefs on the perceived-ideal relationship than we did, we think this finding may be due to the specific wording of the items used to operationalize these beliefs. People were asked how important they thought merit is to get ahead in life, which seems to reflect a preference for the merit principle (Davey et al., 1999), rather than a description of the factual meritocracy of the system. Conversely, the operationalization of equality of opportunity beliefs assessed respondents' credence that, in their country, everyone has an equal chance for getting ahead; which seems to be descriptive in nature. Given the different implications of prescriptive versus descriptive beliefs for the legitimation of inequality (Son Hing et al., 2011),, it is worth noting that meritocracy as a prescriptive notion works as a moral principle and does not necessarily translate into a system justifying ideology, while descriptive beliefs do (Son-Hing et al., 2011. Thus, the larger influence of equality of opportunity beliefs 
might be a result of the greater importance of descriptive beliefs in the justification of economic inequality, rather than a result of the content of these beliefs in itself.

Although objective economic inequality—Gini index — did not affect ideal economic inequality in this research, we must not lose sight of the potential pernicious effect that actual levels of inequality might have on the legitimacy of inequality. As Schröder (2017) showed, objective inequality can feed a vicious cycle where higher economic inequality leads to greater acceptance of inequality. Our research suggests that this may be further exacerbated by system justifying beliefs in the sense that the perceived-ideal inequality relationship is enhanced as a function of individuals' motivations, and the ideological climates in which they live. Then, the more actual inequality there is, the more inequality people are likely to perceive and, consequently, to desire or tolerate; however, this is particularly true if individuals — or those around them-endorse system justifying beliefs.

What we can take away from this research is that the mere perception that economic inequality is high is not enough to encourage people to work towards eliminating it (rather, the opposite), and that system justifying beliefs (both at the individual and the societal level) can make this worse. In this regard, counteracting system justifying beliefs may be a first step toward attenuating — and perhaps breaking down - the vicious cycle. If we want to reduce societal inequality, it is important to discuss the narratives that people endorse, and work on creating new repertoires that challenge widespread system justifying beliefs, while at the same time meeting underlying psychological needs as meaning, order, or stability. Research on the legitimacy of economic inequality is not just an ideological issue, but a way to understand how our perceptions and beliefs can shape the world that we live in. 


\section{References}

Adler, N. E., Epel, E. S., Castellazzo, G., \& Ickovics, J. R. (2000). Relationship of subjective and objective social status with psychological and physiological functioning: Preliminary data in healthy, White women. Health Psychology, 19(6), 586-592. http://doi.org/10.1037/0278-6133.19.6.586

Bar-Tal, D. (2007). Sociopsychological foundations of intractable conflicts. American Behavioral Scientist, 50(11), 1430-1453. http://doi.org/10.1177/0002764207302462

Bar-Tal, D. (2000). Shared beliefs in a society: Social psychological analysis. Shared beliefs in a society. California: Sage Publications.

Bar-Tal, D., Sharvit, K., Halperin, E., \& Zafran, A. (2012). Ethos of conflict: The concept and its measurement. Peace and Conflict: Journal of Peace Psychology, 18(1), 40-61. http://doi.org/10.1037/a0026860

Bar-Tal, D., Raviv, A., Raviv, A., \& Dgani-Hirsh, A. (2009). The influence of the ethos of conflict on Israeli Jews' interpretation of Jewish-Palestinian encounters. Journal of Conflict Resolution, 53(1), 94-118. http://doi.org/10.1177/0022002708325942

Barr, D. J., Levy, R., Scheepers, C., \& Tily, H. J. (2013). Random effects structure for confirmatory hypothesis testing: Keep it maximal. Journal of Memory and Language, 68(3), 255-278. http://doi.org/10.1016/j.jml.2012.11.001

Bates, D., Mächler, M., Bolker, B. M., \& Walker, S. C. (2015). Fitting linear mixedeffects models using lme4. Journal of Statistical Software, 67(1), 1-48. http://doi.org/10.18637/jss.v067.i01

Bitektine, A. (2011). Toward a theory of social judgments of organisations: The case of legitimacy, reputation, and status. Academy of Management Review, 36(1), 151179. http://doi.org/10.5465/amr.2009.0382

Bitektine, A., \& Haack, P. (2015). The "macro" and the "micro" of legitimacy: Toward a multilevel theory of the legitimacy process. Academy of Management Review, 4O(1), 49-75. http://doi.org/10.5465/amr.2013.0318

Brown-Iannuzzi, J. L., Lundberg, K. B., \& McKee, S. (2017). The politics of socioeconomic status: How socioeconomic status may influence political attitudes and engagement. Current Opinion in Psychology, 18, 11-14. http://doi.org/10.1016/j.copsyc.2017.06.018

Buttrick, N. R., \& Oishi, S. (2017). The psychological consequences of income inequality. Social and Personality Psychology Compass, 11(3), e12304. http://doi.org/10.1111/spc3.12304

Castillo, J. C. (2011). Legitimacy of inequality in a highly unequal context: Evidence from the Chilean case. Social Justice Research, 24(4), 314-340. http://doi.org/10.1007/s11211-011-0144-5

Castillo, J. C. (2012a). Is inequality becoming just? Changes in public opinion about 
economic distribution in Chile. Bulletin of Latin American Research, 31(1), 1-18. http://doi.org/10.1111/j.1470-9856.2011.00605.x

Castillo, J. C. (2012b). La legitimidad de las desigualdades salariales. Una aproximación multidimensional. Revista Internacional de Sociología , 70, 533-560. http://doi.org/10.3989/ris.2010.11.22

Central Intelligence Agency (2018). Guide to country profile (Economy). The world factbook. Retrieved January $27^{\text {th }}$ from:

https://www.cia.gov/library/publications/resources/the-worldfactbook/docs/profileguide.html

Cimpian, A., \& Salomon, E. (2014). The inherence heuristic: An intuitive means of making sense of the world, and a potential precursor to psychological essentialism. Behavioral and Brain Sciences, 37(05), 461-480. http://doi.org/10.1017/S0140525X13002197

Costa-Lopes, R., Dovidio, J. F., Pereira, C. R., \& Jost, J. T. (2013). Social psychological perspectives on the legitimation of social inequality: Past, present and future. European Journal of Social Psychology, 237, 229-237.

Davey, L., Bobocel, R., Son Hing, L. S., \& Zanna, M. P. (1999). Preference for the Merit Principle Scale: An indidual difference measure of distributive justice preferences. Social Justice Research, 12(13), 223-240. http://doi.org/10.1023/A

Duru-Bellat, M., \& Tenret, E. (2012). Who's for meritocracy? Individual and contextual variations in the faith. Comparative Education Review, 56(2), 223-247. http://doi.org/10.1086/661290

Feldman, S. (1999). Economic values and inequality. In J. P. Robinson, P. R. Shaver, \& L. S. Wrightsman (Eds.), Measures of Political Attitudes (pp. 159-201). California: Academic Press.

Hadler, M. (2005). Why do people accept different income ratios?: A multi-level comparison of thirty countries. Acta Sociologica, 48(2), 131-154. http://doi.org/10.1177/0001699305053768

Heck, R., \& Thomas, S. L. (2015). An introduction to multilevel modeling techniques. MLM and SEM approaches using Mplus. (Third edition). New York - London: Routledge.

Hox, J. J. (2010). Multilevel analysis: Techniques and aplications (Second edition). New York: Routledge.

ISSP Research Group. (2012). International Social Survey Programme: Social Inequality IV - ISSP 2009. Cologne.

Jasso, G. (1978). On the justice of earnings : A new specification of the justice evaluation function. American Journal of Sociology, 83(6), 1398-1419. Retrieved from http://www.jstor.org/stable/2778110

Jasso, G. (2015). Thinking, saying, doing in the world of distributive justice. Social Justice Research, 28(4), 435-478. http://doi.org/10.1007/s11211-015-0257-3 
Jasso, G., Törnblom, K. Y., \& Sabbagh, C. (2016). Distributive justice. In C. Sabbagh \& M. Schmitt (Eds.), Handbook of social justice theory and research (pp. 201218). New York: Springer New York. http://doi.org/10.1007/978-1-4939-3216-0

Jost, J. T., \& Banaji, M. R. (1994). The role of stereotyping in system-justification and the production of false consciousness. British Journal of Social Psychology, 33(1), $1-27$.

Jost, J. T., Gaucher, D., \& Stern, C. (2015). “The world isn't fair”: A system justification perspective on social stratification and inequality. In M. Mikulincer \& P. R. Shaver (Eds.), APA handbook of personality and social psychology, Volume 2: Group processes. (Vol. 2, pp. 317-340). Washington: American Psychological Association. http://doi.org/10.1037/14342-012

Jost, J. T., \& Hunyady, O. (2005). Antecedents and consequences of system-justifying ideologies. Current Directions in Psychological Science, 14, 260-265. http://doi.org/10.1111/j.0963-7214.2005.00377.x

Jost, J. T., Sterling, J. L., \& Langer, M. (2015). From “is" to "ought" and sometimes "not." Journal of Cross-Cultural Psychology, 46(10), 1287-1291. http://doi.org/10.1177/0022022115600268

Kay, A. C., Gaucher, D., Peach, J. M., Laurin, K., Friesen, J., Zanna, M. P., \& Spencer, S. J. (2009). Inequality, discrimination, and the power of the status quo: Direct evidence for a motivation to see the way things are as the way they should be. Journal of Personality and Social Psychology, 97(3), 421-434. http://doi.org/10.1037/a0015997

Kelley, J., \& Evans, M. D. R. (1993). The legitimation of inequality: Occupational earnings in nine nations. American Journal of Sociology, 99(1), 75-125. http://doi.org/10.1086/230230

Kluegel, J. R., \& Smith, E. R. (1986). Beliefs about inequality. Americans' views of what is and what ought to be. New York: Aldine de Gruyter.

Knowles, E. D., \& Lowery, B. S. (2012). Meritocracy, self-concerns, and Whites' denial of racial inequity. Self and Identity, 11(2), 202-222. http://doi.org/10.1080/15298868.2010.542015

Kunovich, S., \& Slomczynski, K. M. (2007). Systems of distribution and a sense of equity: A multilevel analysis of meritocratic attitudes in post-industrial societies. European Sociological Review, 23(5), 649-663. http://doi.org/10.1093/esr/jcm026

Larsen, C. A. (2016). How three narratives of modernity justify economic inequality. Acta Sociologica, 59(2), 93-111. http://doi.org/10.1177/0001699315622801

Ledgerwood, A., Mandisodza, A. N., Jost, J. T., \& Pohl, M. J. (2011). Working for the system: Motivated defense of meritocratic beliefs. Social Cognition, 29(3), 322340. http://doi.org/10.1521/soco.2011.29.3.322

McCoy, S. K., \& Major, B. (2007). Priming meritocracy and the psychological justification of inequality. Journal of Experimental Social Psychology, 43(3), 341351. http://doi.org/10.1016/j.jesp.2006.04.009 
Mijs, J. J. B. (2016). The unfulfillable promise of meritocracy: Three lessons and their implications for justice in education. Social Justice Research, 29(1), 14-34. http://doi.org/10.1007/s11211-014-0228-0

Pedersen, R. T., \& Mutz, D. C. (2018). Attitudes toward economic inequality: The illusory agreement. Political Science Research and Methods, 6215(12), 1-17. http://doi.org/10.1017/psrm.2018.18

Paternoster, R., Brame, R., Mazerolle, P., \& Piquero, A. R. (1998). Using the correct statistical test for the equality of regression coefficients. Criminology, 36(4), 859866.

Preacher, K. J., Zhang, Z., \& Zyphur, M. J. (2016). Multilevel structural equation models for assessing moderation within and across levels of analysis. Psychological Methods, 21(2), 189-205. http://doi.org/10.1037/met0000052

Roemer, J. E. (1998). Equality of opportunity. Cambridge, MA: Harvard University Press.

Rutland, A., Cameron, L., Milne, A., \& McGeorge, P. (2005). Social norms and selfpresentation: Children's implicit and explicit intergroup attitudes. Child Development, 76(2), 451-466. http://doi.org/10.1111/j.1467-8624.2005.00856.x

Schröder, M. (2017). Is income inequality related to tolerance for inequality? Social Justice Research, 30(1), 23-47. http://doi.org/10.1007/s11211-016-0276-8

Shamon, H., \& Dülmer, H. (2014). Raising the question on 'who should get what?' again: On the importance of ideal and existential standards. Social Justice Research, 27(3), 340-368. http://doi.org/10.1007/s11211-014-0217-3

Sharvit, K. (2014). How conflict begets conflict: Activation of the ethos of conflict in times of distress in a society involved in an intractable conflict. Journal of Experimental Social Psychology, 55, 252-261. http://doi.org/10.1016/j.jesp.2014.07.017

Sherif, M. (1936). The psychology of social norms. The psychology of social norms. Oxford, England: Harper.

Shepelak, N. J. (1989). Ideological stratification: American beliefs about economic justice. Social Justice Research, 3(3), 217-231. http://doi.org/10.1007/BF01048450

Shepelak, N. J., \& Alwin, D. F. (1986). Beliefs about inequality and perceptions of distributive justice. American Sociological Review, 51(1), 30-46.

Son Hing, L. S., Bobocel, D. R., Zanna, M. P., Garcia, D. M., Gee, S. S., \& Orazietti, K. (2011). The merit of meritocracy. Journal of Personality and Social Psychology, 101(3), 433-450. http://doi.org/10.1037/a0024618

Sznycer, D., Lopez Seal, M. F., Sell, A., Lim, J., Porat, R., Shalvi, S., ... Tooby, J. (2017). Support for redistribution is shaped by compassion, envy, and self-interest, but not a taste for fairness. Proceedings of the National Academy of Sciences, 
114(31), 8420-8425. http://doi.org/10.1073/pnas.1703801114

Trump, K.S. (2017). Income inequality influences perceptions of legitimate income differences. British Journal of Political Science, 1-24. http://doi.org/10.1017/S0007123416000326

Tversky, A., \& Kahneman, D. (1974). Judgment under uncertainty: Heuristics and biases. Science, 185(4157), 1124-1131.

van der Toorn, J., \& Jost, J. T. (2014). Twenty years of system justification theory: Introduction to the special issue on "Ideology and system justification processes." Group Processes \& Intergroup Relations, 17(4), 413-419. http://doi.org/10.1177/1368430214531509

Walker, H. A. (2014). Legitimacy and inequality. In J. D. McLeod, E. J. Lawler, \& M. Schwalbe (Eds.), Handbook of social psychology of inequality (pp. 353-377). New York - London: Springer. http://doi.org/10.1007/978-94-017-9002-4

Wilkinson, R. G., \& Pickett, K. E. (2017). The enemy between us: The psychological and social costs of inequality. European Journal of Social Psychology, 47(1), 1124. http://doi.org/10.1002/ejsp.2275

Willis, G. B., Rodríguez-Bailón, R., López-Rodríguez, L., \& García-Sánchez, E. (2015). Legitimacy moderates the relation between perceived and ideal economic inequalities. Social Justice Research, 28(4), 493-508. http://doi.org/10.1007/s11211-015-0253-7

World Bank (2018). World development indicators. Data Bank. Retrieved January $27^{\text {th }}$ from: http://databank.worldbank.org/data/reports.aspx?source=WorldDevelopment-Indicators 